Art and Myth of the Ancient Maya 


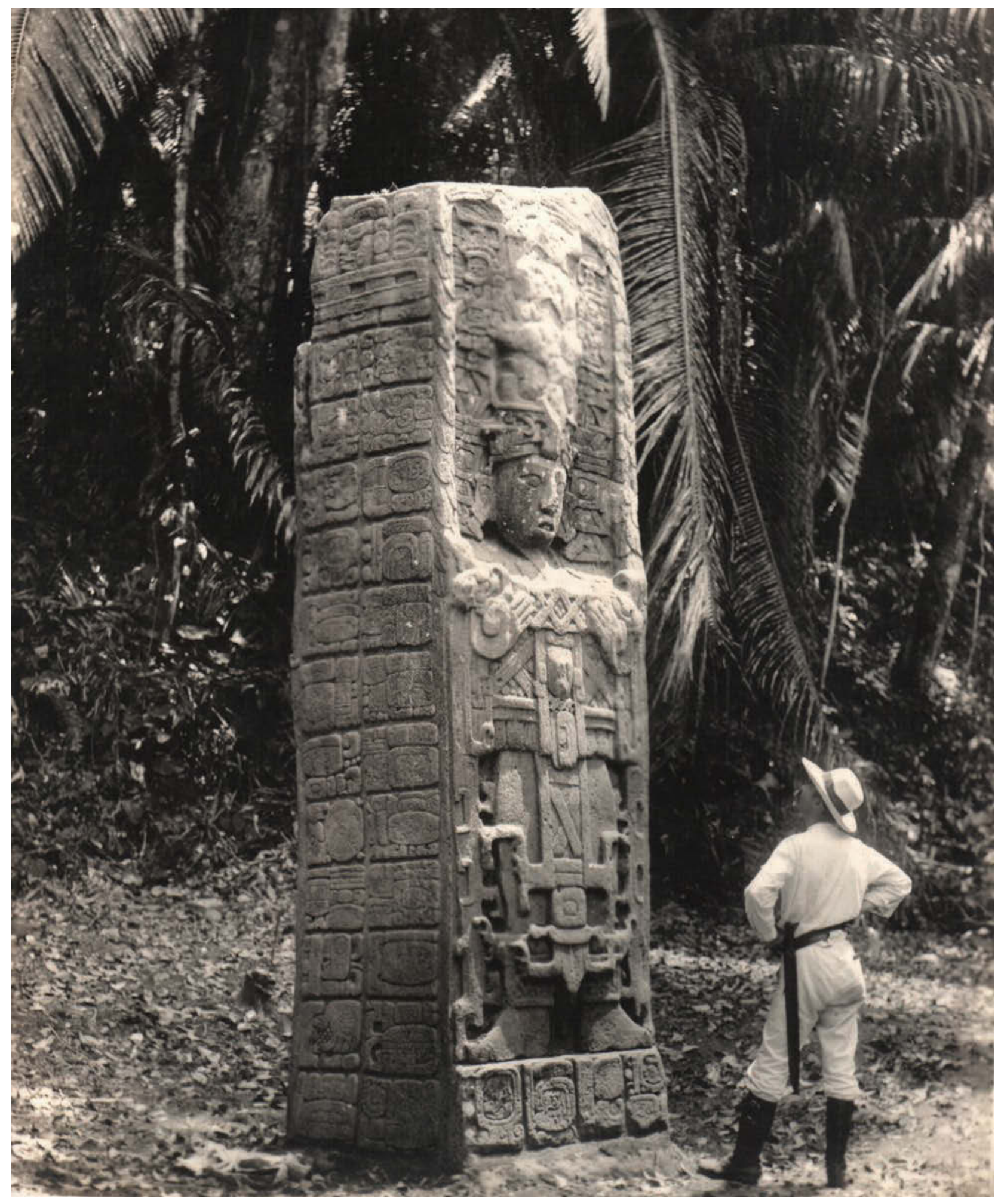




\section{Art and Myth of the Ancient Maya}

Oswaldo Chinchilla Mazariegos 
Published with the assistance of

the Frederick W. Hilles Publication

Fund of Yale University.

Copyright $\odot 2017$ by Oswaldo

Chinchilla Mazariegos.

All rights reserved.

This book may not be reproduced, in whole or in part, including illustrations, in any form (beyond that copying permitted by Sections 107 and 108 of the U.S. Copyright Law and except by reviewers for the public press), without written permission from the publishers.

yalebooks.com/art

Designed by Leslie Fitch

Set in Crimson and Source Sans Pro type by Leslie Fitch

Printed in China through Oceanic Graphic International, Inc.

Library of Congress Control

Number: 2016940998

ISBN 978-0-300-20717-O

A catalogue record for this book is available from the British Library. This paper meets the requirements of ANSI/NIsO Z 39.48-1992 (Permanence of Paper).

1098765432

Jacket: Mural painting, Las Pinturas Sub-1, San Bartolo, Guatemala (details of fig. 74) Frontispiece: Quiriguá Stela C. Photograph by Alberto Valdeavellano, ca. 1915 (fig. 15) 
Para mi esposa, Silvia, y mis hijos, Oswaldo Esteban y Ana Silvia, con amor 
This page intentionally left blank 